\title{
QUEEN'S
UNIVERSITY
BELFAST
}

\section{Assessing the impact of market logic and long-term strategic plans of top management in share buyback decisions}

Demirag, I., Kungwal, T., \& Bakkar, Y. (2021). Assessing the impact of market logic and long-term strategic plans of top management in share buyback decisions. Managerial Finance. https://doi.org/10.1108/MF-07-20210336

Published in:

Managerial Finance

Document Version:

Peer reviewed version

Queen's University Belfast - Research Portal:

Link to publication record in Queen's University Belfast Research Portal

Publisher rights

Copyright 2021, Emerald Publishing Limited.

This work is made available online in accordance with the publisher's policies. Please refer to any applicable terms of use of the publisher.

\section{General rights}

Copyright for the publications made accessible via the Queen's University Belfast Research Portal is retained by the author(s) and / or other copyright owners and it is a condition of accessing these publications that users recognise and abide by the legal requirements associated with these rights.

Take down policy

The Research Portal is Queen's institutional repository that provides access to Queen's research output. Every effort has been made to ensure that content in the Research Portal does not infringe any person's rights, or applicable UK laws. If you discover content in the Research Portal that you believe breaches copyright or violates any law, please contact openaccess@qub.ac.uk. 


\title{
Assessing the impact of market logic and long-term strategic plans of top management in share buyback decisions
}

\section{Istemi Demirag ${ }^{\mathrm{a}}$, Thanamas Kungwal ${ }^{\mathrm{b}}$, Yassine Bakkar}

${ }^{a}$ School of Business and Governance, Tallinn University of Technology, Tallinn, Estonia.

${ }^{\mathrm{b}}$ Keele Business School, Keele University, Staffordshire, UK.

${ }^{\mathrm{c}}$ Queen's Management School, Queen's University Belfast, Belfast, UK.

\begin{abstract}
This paper investigates the processes of share buybacks by UK firms from stakeholders' perspectives. We use in-depth interviews with stakeholders from eight stock-listed firms as well as examining their annual reports and other publicly available data. Findings suggest that share buybacks involve a wider range of stakeholders' rational interests and management perspectives, than market incentives as suggested in the extant literature. The results show that share buybacks enable firms to strategize operational plans towards their long-term corporate goals. The findings contribute to literature on corporate pay-out policies in the context of short-term financial objectives versus long-term strategic objectives of stakeholders.
\end{abstract}

\section{$\underline{\text { JEL codes: }}$}

E44, E60, G14, G40

\section{Keywords:}

Share buybacks, pay-out policy, stakeholders' incentives, short-termism, management control, firm performance. 


\section{Design/methodology/approach:}

We use in-depth interviews with stakeholders from eight listed UK firms as well as examine their publicly available data.

\section{Purpose:}

This paper investigates stakeholders' perspectives of share buybacks in the context of timehorizons of investment decisions and strategy.

\section{Findings:}

Findings suggest that share buybacks involve a wide range of stakeholders' rational interests and long-term management perspectives as they enable firms to strategise operational plans towards their long-term corporate goals.

\section{$\underline{\text { Research limitations: }}$}

The findings are based on interviews with a small number of share buyback firms and the findings, therefore, may not be generalised to all firms.

\section{Practical implications:}

The results show that share buybacks may be part of the long-term interests of firms and not necessarily used as part of short-term EPS increases as suggested in the extant literature.

\section{Originality:}

The findings contribute to the literature on corporate pay-out policies in the context of shortterm financial objectives versus long-term strategic objectives of stakeholders. They show that share buybacks can be an important part of firms' long-term strategic considerations.

\section{JEL codes:}

E44, E60, G14, G40

\section{Keywords:}

Share buybacks, pay-out policy, stakeholders' incentives, short-termism, management control, firm performance. 
"The Company share repurchases can often play a role in a balanced capital allocation strategy.... Striking this balance requires a deep understanding of a company's long-term strategic plan."

(Securities and Exchange Commission, The Boeing Company, 20 December 2019)

\section{Introduction}

Deregulation in financial markets has prompted the popularity of share buybacks (or share repurchases) across the developed stock markets and among firms (see e.g., Jagannathan et al., 2000; Peyer and Vermaelen, 2009; Brav et a1., 2005; Vermaelen, 2005; Kim et al., 2013). Share buybacks provide a unique type of corporate distribution of cash as they allow firms to repurchase shares from shareholders at a flexible price and time, especially when they have a cash surplus. Shareholders retain the option of whether they sell their shares or not (Autore et al., 2019). Share buybacks have gained more popularity in the UK since 2004 (Renneboog and Trojanowski, 2011; Dedman et al., 2014)

Prior studies have mainly examined market reactions of share buybacks: managers' motivations for share buybacks and their impact on firm optimal capital structure (Stonham, 2002; Brav et al., 2005); capital market reactions to the announcement of share buybacks (Rau and Vermaelen, 2002; Oswald and Young, 2008); and firms' characteristics in share buyback practices (Andriosopoulos and Hoque, 2013). This literature suggests that firms use rational decisions to arrive at market-based financial solutions when faced with share buyback decisions. Overall, it shows that corporate pay-out policies are heavily influenced by the pressures of activist investors (see e.g., Gasper et al., 2013; Autore et al., 2019; Ghaly et al., 2020; Gryglewicz et al., 2020; Karpoff, 2021).

However, very little is still known on how internal management decisions on share buybacks are influenced by other stakeholders' perspectives (Coleman et al.,2010). Only a few empirical studies use stakeholder perspectives to examine the motivations for share buybacks (see e.g., Reynolds et al., 2006; Dixon et al., 2008; Coleman et al.,2010) but none of these studies examine stakeholder groups interests in the process of share buybacks from the perspectives of aligning corporate strategy. To date, little attention has been paid to how managers interact with investors and other stakeholders, with potential long-term considerations in the process of share buybacks (Edmans, 2020).

This study aims to fill this gap by undertaking interviews and using archival data to better understand these conflicting interactions between managers and other stakeholders, in the context of strategic considerations of share buybacks in the UK. We explore corporate management processes of share buyback announcements and the buyback behaviour of UK firms, re-examining the role of all stakeholder groups from top managers of companies to better understand their nuanced arguments and assess the gaps in existing literature, current practices, 
and policy choices. This study addresses these issues using in-depth interviews with one senior financial analyst and eight finance directors or their equivalents from eight firms listed on the London Stock Exchange (LSE), which were active in repurchasing their shares over the 20112013 period.

The study contributes to the literature in three significant ways. First, we show that the practice of share buybacks is shaped by social, political, organisational, and strategic factors, and using data from interviews and extensive thematic analysis, we explain how long-term strategic issues are considered for an effective share buyback process. Second, we provide empirical evidence on a myriad of stakeholders' perspectives in share buyback decisions in practice. Third, we contribute to the extant literature on managers' short-termism in the context of strategy formations and show how longer-term objectives are considered in share buyback programmes.

The rest of the paper is structured as follows. Section 2 discusses the general trends in share buyback activity and the reasons for buyback schemes. Section 3 outlines the research methods and data collection. Section 4 presents the findings. Section 5 provides a summary and some concluding remarks.

\section{The Literature review}

Share buybacks are considered an important financial strategy in the US and the UK and are drawing increasing attention from corporate managers, institutional investors, researchers, and regulators. Vermaelen (2005) argues that the global increase in share buybacks is mainly due to tax changes, shareholder value maximisation, and the growth of stock options in executive compensation packages. ${ }^{1}$ Many previous studies have documented that open market buyback programmes are most frequent in both the US and the UK financial markets (see e.g., Ikenberry and Vermaelen, 1996; Lease et al., 2000; Rasbrant, 2011).

Renneboog and Trojanowski (2011) found that share buybacks have become increasingly popular since the early 2000s in the UK. Geiler and Renneboog (2015) show that share buybacks grew considerably during this period and go together with the steady decline in the proportion of dividend-paying UK firms. ${ }^{3}$ Similarly, Dedman et al. (2014) find that the

\footnotetext{
${ }^{1}$ Offers to share buybacks for cash can be executed in several ways: (i) fixed price tender offers repurchasesTORs; (ii) Dutch auction buybacks; (iii) transferable put rights distribution; (iv) target stock buybacks; and (v) open market repurchases-OMRs (Lease et al., 2000). In our research, we found that (i) and (v) were the most common methods used in the UK.

${ }^{2}$ In the UK, tax-exempt investors preferred dividend payments to any form of share repurchases, due to the fact that share repurchases would increase the per share capital of the remaining outstanding shares, which would attract a 'presumed' dividend tax, and provide the opportunity to claim a tax credit on distribution. However, with the changes in the tax code (July 1, 1997), investors became indifferent between dividends and share repurchases, as is the case in the US. More evidence on the transformation of pay-out policies in the UK is provided by Geiler and Renneboog (2010) and Renneboog and Trojanowski (2011).

${ }^{3}$ For more evidence and empirical support see: Grullon and Michaely (2002) for the US case, von Eije and Megginson (2008) for a broad European study, and Ota et al. (2019) for a Japanese experiment.
} 
proportion of firms only repurchasing shares has increased, but is still relatively small, whereas the proportion of firms both repurchasing shares and paying dividends has significantly increased.

The increase in share buybacks has been examined by several studies presenting a variety of firms' motivations and corporate finance theories that explain occurrences of repurchased shares (Jagannathan et al., 2000). Earlier studies on management incentives of share buyback schemes are motivated by capital structure and leverage (Dittmar, 2000; Rau and Vermaelen, 2002; Jagannathan and Stephens, 2003); free cash flow and investment theory (Jagannathan et al., 2000; Grullon and Michaely, 2002; Farrell et al., 2013); information-signalling theory (Grullon and Ikenberry, 2000; Grullon and Michaely, 2002; Grullon and Michaely, 2004; Brav et al., 2005; Peyer and Vermaelen, 2009); information asymmetry and agency theory (La Porta et al., 2000; Fried, 2005); ownership structure and corporate control theory (Ginglinger and L'Her, 2006); and an earnings per share (EPS) target (Brav et al., 2005; Hribar et al., 2006).

These studies, however, show that share buyback decisions are driven by rational financial perspectives that are linked to managerial short-termism rather than a firm's long-term objectives. It is argued that managers are pressured to cut long-term investments, including intellectual capital investment, research and development (R\&D), and merger and acquisition (M\&A) to meet short-term objectives (Porter, 1992). Nguyen et al. (2020) find that share repurchases have a negative relationship with firm innovation, which requires long-term investments. Similarly, Ghaly et al. (2020) indicate that cash to invest in human labour and improve production efficiency is reduced when firms repurchase shares. Almeida et al. (2016) indicate that firms that are in danger of missing their EPS forecast to display a wider use of buyback programmes as opposed to firms that meet their EPS forecast, and that management would rather meet their EPS forecast through share buybacks than partake in investment or increased employment Chen, et al. (2015).

Other studies in this area have focused on the interests of investors from different time horizons, including short-term and long-term investors (see e.g., Gasper et al., 2013; Autore et al., 2019; Ghaly et al., 2020). However, little attention is paid to all stakeholders' perspectives with long-term and more strategic objectives (see Freeman, 1984; Buono and Nichols, 1990). Stakeholders not only include a firm's financial claimants, but also employees, customers, government officials, and communities (Gomes et al., 2010). There might be a conflict of interest between investor stakeholders and non-investor stakeholders. Holder et al. (1998) found that non-investor stakeholders have an impact on a firm's financial strategy. A managerìs decision includes a trade-off between different groups' interests as each stakeholder may have different interests (Kinley and Tadaki, 2004; Abyad, 2013). Kajula et al. (2012) and Edmans (2020) argue that managers ensure that all stakeholders are involved when management decisions are made and balance short-term and long-term stakeholders' interests with the best interests of the firm. This is often referred to as stakeholder management. Short-term operational processes and long-term 
strategic decisions are intertwined, and they evolve interactively through collaboration with several stakeholders (Demirag et al.,1994; Carlsson-Wall et al., 2015).

In the next section, we discuss our research methods and data collection.

\section{Research methods and dataset}

The empirical literature on share buybacks is mainly based on questionnaire studies with limited in-depth interview data (Mitchell et al., 2001; Dixon et al., 2008). Only a few studies conduct in-depth interviews to determine the factors that drive share buyback decisions (Brav et al., 2005; De Jong et al., 2013); but these studies do not examine the management decisionmaking process at the firmlevel. To address this gap, the research methods used in this study include, (i) Primary data captured from an in-depth interview method as this provides each company's perspective on share buyback programmes; and (ii) Secondary data collected from Eikon-Datastream, annual reports, and newspapers, providing a deeper understanding of the share buyback decisions within those companies.

We study eight firms headquartered in the UK of which Eikon specialisations are industrials, telecommunication, utilities, financial services, and energy. Our sample consists of the leader firms in their respective industries, and major players in the UK share buyback programme activity over our study period. The sample period is, to a large extent, fixed by the buyback programme and by the availability of comparable data over time for all firms. The market value of the eight listed firms included in our interviews accounts for approximately $31 \%$ of the total market capitalisation of all firms recorded in the FTSE 100 Index as reported in EikonDatastream analytics and studies.

The research themes and questions used in the literature review and analysis of our interview data were developed between the researchers from prior literature (Cornell and Shapiro, 1987; Holder et al., 1998; Brav et al., 2005; Dixon et al., 2008; Carlsson-Wall et al., 2015). A sample of our semi-structured questions is included in Appendix A. We conducted in-depth interviews with one senior financial analyst and eight finance directors or their equivalents, of firms listed on the LSE. Participants were selected based on analysis of published data and company annual reports. Interviews were carried out with companies with a history of making share buybacks in the three years before 2013 (i.e., 2011, 2012, and 2013). Invitation letters and subsequent follow-up letters, emails, and phone calls to non-respondents were sent/made to one hundred potential interviewees between April 2015 and May 2016, from which nine finance directors/analysts were selected based on availability and willingness to participate in the study. Respondents were assured that any information they contributed would remain confidential and anonymous. Detailed questions were drawn up to elicit information regarding the interviewee's institution share buyback activities in the three years of our study, including the level of buyback activity, incentives behind the activity, and how all stakeholders were affected 
by the share buyback process. The interviews were recorded using a tape recorder and later transcribed, and extensive notes were taken. Details of interviews are provided in Table 1.

\section{[Insert Table 1 about here]}

All transcribed interview files were collated into one database. To identify the main keywords and analyse our results, we applied a six-phase thematic analysis approach in line with the convention in this literature (see Braun and Clarke, 2006; Ahmed et al., 2020). Following the insights from this convention, Table 2 displays the six-phase approach of the thematic analysis adopted to treat our data.

\section{[Insert Table 2 about here]}

Following the steps in the six-phase thematic approach, we developed two main themes and ten sub-themes. See Table 3 for the main themes and sub-themes developed.

\section{[Insert Table 3 about here]}

Finally, we completed the process by analysing the interview data using the themes developed, capturing all relevant narrative analyses for each stakeholder (e.g. investors and non-investor stakeholders) identified in the study.

In addition to the data collected through interviews, we analysed three consecutive years of annual financial reports of the interviewed companies. This involved scanning of approximately 2700 (A4) pages. Applying narrative analysis helped us to enhance the argumentation and knowledge regarding the issues surrounding the decision to use share buybacks (Llewellyn, 1999). In our analyses, we developed the main themes identified from prior literature, presented in Table 3. Key quotations were identified and then extensively discussed by all the researchers iteratively until a common agreement was reached on which of the selected quotations represented the most common themes in the companies' annual accounts.

\section{Empirical findings}

In the following analysis of our findings, we find that it is not just shareholders who are intrinsic to a managerìs decision to complete share buybacks, but many more stakeholders are affected by and therefore influence share buyback activity. Figure 1 breaks down significant stakeholders found in our study into (i) investor stakeholders: shareholders; and (ii) non-investor stakeholders: customers, employees, competitors, etc. (Friedman, 1970; Cornell and Shapiro, 
1987; Holder et al., 1998; Jensen, 2002). Non-investor stakeholders varied between firms and included employees, customers, creditors, analysts, government bodies, and policy-makers. Each group had an interest in how firms engage in the share buybacks process. Moreover, these groups also influenced a manager's behaviour either positively or negatively in their decision to instigate a buyback programme.

Through undertaking interviews with all the significant stakeholders, we now examine the share buyback process from a managerial perspective, focusing on firms' financial structures, strategy, and performance; asymmetric information and signalling issues; and corporate governance and the non-investor issues.

\section{[Insert Figure 1 about here]}

\section{Firms' financial structures, strategy, and performance}

Drawing on Von Eije and Megginson (2008), in the following section we explore the link between investor stakeholders' incentives and corporate management decisions on share buyback announcements. These incentives highlight and explain the relationships between firms' managerial behaviours and their financial strategies, both short-term and long-term (Demirag, 1995a). We explain how investor stakeholders have an impact on management incentives to initiate share buyback schemes and how managers view these incentives and then react to them in the context of the share buyback process.

Dividends are important sources of income for shareholders. Firms are expected to distribute wealth back to their stakeholders.

"The ordinary dividend is the core element of shareholder remuneration, with any surplus capital distributed via special dividend or share buybacks."

(Company 1, Annual Report 2013, p. 13)

Firms prioritise their financing hierarchy by preferring internal financing sources to external financing sources and managers' decisions on shares buybacks may have an impact on the capital structure of the company (Kulchania, 2016). Dixon et al. (2008) for example argue that managers will consider the capital structure of their firms and decide on share buyback decisions, as they attract investors and raise external recapitalisation, and preserve their controlling positions. For expositional purposes, an Investor Relations Director outlined how their firm's financial factors, including short-term and long-term performance, strategic initiatives, and financial strategy affected their firm's share buybacks decision:

\footnotetext{
${ }^{4}$ Due to confidentiality, company names cannot be revealed. Instead, the actual company names are presented Company 1 , Company 2 , etc.
} 
îI we think that projecting out for two or three years our leverage is going to be sort of below the two times then that is the moment when you might consider, you know we vote for it, you might consider a share buyback. Ü. So, the only times we have had excess capital, when we have not been reinvesting, buying spectrum, paying dividends, doing mergers and acquisitions, has been when we have made disposals."

(Company 1, Investor Relations Director)

A Group Director states that the firm ensures it sustains its internal source of funding and might process share buyback only if it has excess equity:

ilf we have a lot of investment opportunities then we will keep the equity. In times when we do not necessarily need that extra equity and our balance sheet is strong, we will then elect to buy back up to an equivalent amount of those shares."

(Company 5, Group Director)

Such insights suggest senior managers place importance on long-term capital structure and are expected to pursue organic investment opportunities and ensure that their wealth distributions are in line with their long-term capital structure target.

When management sets financial strategies, we found that firms considered both shortterm and long-term strategies. Two companies interviewed clearly stated this vision in their annual reports.

"Drive shareholder value by improving financial performance and competitive positions across the business. The current environment is increasingly competitive and, to deliver growth in shareholder value, the Group will focus on generating strong cash flows and profits. Improving efficiency in the Group's operations."

(Company 2, Annual Report 2012, p.17)

"We continued to focus investment on growth opportunities and returned significant value to shareholders through increased dividends and a share buy-back programme."

(Company 3, Annual Report, 2013, p.5)

Shareholders arguably prefer firms to pay corporate distribution to shareholders instead of investing in negative net present value (NPV) projects. An investor relations director suggested that firms lacking positive investment opportunities may prefer using their excess cash to repurchase shares.

$\hat{1} S o$ as there was not really very much $M \& A$ opportunity I suppose, ..., so share buybacks became the sort of norm, just basically returning to shareholders." 
Corporate distributions reduce excess cash, and therefore, this reduces the opportunity for managers to misuse these funds. Therefore, senior management considered repurchasing shares when their firms have an uncertain excess cash flow to reduce the agency costs, as indicated in Company 2 annual report.

"Group expects to continue to meet its pension obligations, invest in research and technology and pursue other organic investment opportunities and plans to pay dividends in line with its policy of long-term sustainable cover of around two times underlying earnings. Investment in valueenhancing acquisitions and returns to shareholders through a share buyback will be considered in line with our clear and consistent strategy and capital allocation policy."

(Company 2, Annual Report 2019, p.17)

Two senior managers revealed the importance for their firms to prioritise their alternative business options relating to diversification and growth strategies, development, and innovation before repurchasing shares.

îHow to articulate a capital allocation framework. So, what it simply says is that we have four priorities for use of capital. Firstly, we want to repay creditors. We also want to reinvest capital in the business for organic growth. So that means things like $R \& D$ expenditure, capital expenditure, and other investments in the business. Secondly, we want to pay a progressive dividend to our shareholders on an annual basis. Progressive means growing a dividend in line with earnings. Thirdly we would allocate capital to acquisitions in line with our stated strategy. And then fourthly and finally, if we determined, having looked at one, two, and three, that we had excess capital, we would seek to return it to shareholders."

(Company 3, Group Treasurer)

îI am just saying for us share buybacks is when we have excess capital after every other mouth has been fed.And by excess capital, I mean when we are clearly at the very lowest end of our leverage window."

(Company 1, Investor Relations Director)

We found that the firms interviewed on the whole prefer to plan their long-term strategy to include further investment and/or enhance their M\&A arrangements rather than conducting share buybacks. We did not find much evidence to suggest that activist shareholders pressured management into market share buybacks to benefit short-term objectives at the expense of investing in long-term value-adding projects (Bivens and Weller, 2005). This may be because, in the UK, there is little indication of activist involvement in the motives of buyback decisions, and therefore less pressure on firms' management decisions to conduct share buyback programmes (see Lazonick, 2014; Kaplan, 2018; Autore et al., 2019). Barton et al. (2016) also 
found that the respondents from companies with headquarters in Europe were significantly less likely to report increasing short-term pressure (64\%) than their peers based in developing countries $(82 \%)$.

\section{Asymmetric information and signalling issues}

The information and signalling perspective can also be used to explain the management incentives of share buyback schemes with a mix of short-term and long-term purposes. Under the information and signalling explanation, share buybacks may be a proxy to signal inside information to investors (e.g., see, Grullon and Ikenberry 2000; Grullon and Michaely, 2002 and Grullon and Michaely, 2004). If a company believes that its shares are undervalued, it may repurchase shares to convey to the market firm-specific trends, as the market positively responds to share buyback increases and responds negatively to share buyback decreases (Chang and Sullivan, 2007; Dedman et al., 2014).

Firms believe that repurchasing shares will lead to an increase in short-term share prices, in the belief that their share price is undervalued (Demirag, 1995b; Grullon and Ikenberry 2000; Brav et al., 2005; Peyer and Vermaelen, 2009; Dittmar and Field, 2015). An example of this was explained by one of the Group Treasurers as follows:

$\hat{1}$ All other things being equal, if you buy back shares the liquidity is reduced, so, therefore, the share price tends to drive up."

(Company 8, Group Treasurer)

Conversely, several interviewees argued that share price was not an important aspect of their buyback programmes. Some admitted that they were unsure if it was the actual buyback programmes that affected their share price before share buyback announcements. Two interviewees stated that if a firmì volume of share buybacks is not high, then this will not be sufficient to drive an increase in share price.

îThe volume of repurchasing we do is not of itself sufficient to drive the price.I think the signalling of intent is, I would say, supportive of the price in a general concept."

(Company 2, Investor Relations Director)

$\hat{1}$ As it happens effectively what we are announcing there is a smallish disposal and a smallish share buyback, and the share price did not move that much".

(Company 3, Group Treasurer) 
The common view among the interviewees was that the causal relation between share buyback announcements and the degree of undervaluation in the repurchasing firm's share price is not straightforward across firms in the UK.

$\hat{1}$ Right now the share price is not a primary consideration of buyback. Ü. We do not say the share price is looking low letis go and buy or on the flip side we are not saying the share price is high, we do not think the company is worth that, letis not buy it.It is not."

(Company 5, Group Director)

These aforementioned insights are consistent with Brockman et al. (2008) and Hillert et al. (2016), who argued that undervaluation is not a dominant motivating factor for share buybacks.

In addition, we find that firms' management repurchase shares to improve the firms' long-term EPS, instead of focussing on their short-term share price strategy. Long term incentives in share buybacks were clearly stated in one of the company accounts.

"To motivate and reward longer-term performance linked to the long-term strategy and share price of the Company."

(Company 3, Annual Report 2013, p.66)

Two senior managers indicated the presence of mid-term or long-term strategies to repurchase shares to increase shareholder's value by raising their EPS improvement and that these must be carefully planned and monitored, and not diminish the firms' value.

îMost responsible companies buying back shares will do so in such a way that is designed not to affect the price.... That, over the long term, will have an impact on the price. But on a day-to-day basis, it should not, if the buyback is done sensibly and responsibly."

(Company 7, Managing Director)

$\hat{1} I$ do not see that as short-termism; I see that the business is owned by a smaller number of shares and that is the way, by driving down the number of shares, you drive up the value per share."

(Company 6, Director of Corporate Finance)

Our findings suggest that firms do not launch their share buyback programmes to improve their share prices or EPS for short-term goals. Similar findings were also found by BEIS (2019) in that no FTSE 350 firms successfully used share buybacks to achieve an EPS target.

\section{Corporate governance and the non-investor issues}

Several firms interviewed indicated that they have used their share buyback policy as a tool to control the number of shares in the market, to reduce agency conflicts, and to prevent a share 
dilution problem, especially if the managers reward themselves with share-based compensation, by issuing ESOP. Two top managers mentioned that the importance of share buybacks is to control and diminish the dilution of outstanding shares and EPS.

$\hat{1}$ Some peopleìs remuneration is in shares. If you do nothing, then the company issues more shares to grant those shares to the employee. That means that the number of shares in the issue gets diluted so therefore earnings per share goes down. What we would like to do is, at least in a year, buy as many shares as are delivered to employees for remuneration."

(Company 6, Director of Corporate Finance)

"Therefore, the buyback that we do today is very much around trying to help reduce the amount of dilution that shareholders suffer from the various employee share options or share plans that we have."

(Company 4, Group Director)

Our findings are in line with previous empirical studies, concluding that there is a positive relationship between share-based remuneration and share buybacks (Fenn and Liang, 2001; Kahle, 2002; Geiler and Renneboog, 2016). Moreover, this implies that firm managers would wish to avoid any agency conflicts and would instead attempt to engender a strong relationship with their shareholders, leading to more share buyback programmes.

We also found that factors affecting managements' decisions on share buybacks regarding non-investor stakeholder perspectives were at least equal, if not more important, than investor stakeholder perspectives.

Analysts provided publicly available reports on a companyìs financial situation including its corporate pay-out policy. On the surface, shareholders relied on analysts' reports when they were choosing which company to invest in, or whether to retain an investment in a company. In this context, a manager may initiate a share buyback programme to influence analysts to report that a company's financial situation is solid with high long-term performance. As one of the Investor relations directors explains:

$\hat{1} Y$ ou are trying to explain to the analyst what you are doing, and how you are doing it, you convince them.You have to tell them that.But at the same time, you cannot really tell them that because it is confidential."

(Company 2, Investor Relations Director)

Creditors are another non-investor group that influences managers to avoid share buybacks at least until their loans are paid back. They are a negative driver to a manager initiating share buyback programmes as explained by a Group Treasurer: 
$\hat{1}$ So, what it simply says is that we have four priorities for use of capital. Firstly, we want to repay creditors. Ü. And then fourthly and finally, if we determined, having looked at one, two, and three, that we had excess capital, we would seek to return it to shareholders."

(Company 3, Group Treasurer)

Firms must also adhere to the stipulated rules surrounding buybacks including pricing and frequency. These rules can negatively affect a manageris ability to decide upon the amount and timing of share buybacks. Regulators in the UK are guided by several acts, namely, the Companies Act 2006, the UK Listing Authority (UKLA), and Listing Rules governed by the Financial Conduct Authority. The UK regulatory environment discourages share buybacks designed to take advantage of an undervalued share price (Rau and Vermaelen, 2002). Dhanni and Roberts (2009)explained that regulations surrounding buyback activity in the UK can be broadly classified into three groups:

(i) Operational requirements set up by the UKLA and from the Companies Act 2006 (CA2006).

(ii) Conditions agreed with shareholders.

(iii) Reporting requirements as set out by the UKLA.

In the UK, limits on buyback size and on the use of repurchased shares are governed by these regulations. Firms listed on the LSE or the Alternative Main Market (AIM) are allowed to hold up to $10 \%$ of their issued shares in treasury (Company Act 1985). Moreover, a company can only make purchases of its shares of less than $15 \%$ of any class of its equity shares (excluding treasury shares). If a company purchases its own shares of $15 \%$ or more of any class of its equity shares (excluding treasury shares) this will be treated as a tender offer (Financial Conduct Authority, 2016). These regulations may affect a firm's strategy concerning with planning its share buyback programme.

An interviewee reveals that both the size and price of share buybacks transactions are regulated by financial regulators.

"There are... Under the UK listing rules, you can only buy... Well, I think...I have got a feeling there may be a formal limit of $15 \%$ of the daily volume in the shares through the main exchange, through the London Stock Exchange."

(Company 2, Investor Relation Directors) The decision to launch and operate a share buyback is further complicated as each firmis corporate distribution policy is regulated by financial regulators, who can impose limits on the pay-out policy. This was presented by one of the interviewees:

$\hat{1}$ You negotiate the price with the regulatory body? 
Yes.It is done differently in the US and the UK.In the UK, it is more done

on a forward-looking price.... You have your plan and then whatever the customer requirements and stakeholder requirements are."

(Company 5, Group Director)

One strategy applied by firms is to reward their employees by repurchasing ESOP shares from them. When firms repurchase shares from their employees and ex-employees, they often buy back at a higher than market price as this consequently remunerates personnel and exhibits an internal improvement in terms of social morality. A Group Director stated that share buybacks are a tool used to reward employees.

"But it is about building engagement and loyalty and all these kinds of things. And it is a way of rewarding our employees, but at the same time, we recognise that it can be seen as a value transfer from all our other shareholders to employees. And so that's why our approach to buyback is just to readdress that."

(Company 4, Group Director)

On the other hand, employees who do not own any shares in the firm for whom they work may potentially be disgruntled by share buybacks as cash is being allocated by managers to repurchase shares that could be used for personal bonuses, investment opportunities, pension schemes, etc.

Competitors' financial strategies may be used to mirror their own capital structure and payout policy. We found that firms often observed and monitored their competitor's capital structure and pay-out policy.

Managers may look to emulate other firms' strategies when planning their financial policies to maximise shareholders' expectations. This was presented by one of the Group Treasurers:

"It may depend on the nature of the industry or the business. Like maybe for your business the shareholders and investors much more appreciate it with the $R \& D$ of the reinvestment stage than these two because they probably see that by doing this, they would give them... The company, we will have the kind of long-term growth."

(Company 3, Group Treasurer)

These findings are consistent with Adhikari and Agrawal (2018), who provide evidence that firms are likely to mimic their peer's financial strategy to maintain their competitive parity.

Furthermore, industry growth/decline may also play a part as a declining industry is likely to do share buybacks. An Investor Relations Director stated that firms are likely to repurchase shares if industry growth is declining and there are no positive return projects to invest in. 
"The cash generative nature of these large defence prime contractors meant that they had no real sort of obvious outlook for the cash that they were generating, so share buybacks became the sort of norm, just basically returning to shareholders."

(Company 2, Investor Relations Director)

\section{Discussion and conclusions}

This paper chiefly explores whether, and if so why, incentives and behaviours towards share buyback decisions and processes are different between investor shareholders and non-investor stakeholders of firms. It re-examines the role of activist agents in firms' decisions to conduct open market share buybacks vis-à-vis managerial short- and long-term decisions.

Previous empirical and theoretical studies on corporate pay-out policies have mainly focused on relevant market-based theories explaining external and internal factors affecting firms' decisions, regarding share buybacks or dividend pay-out policies. Using mainly shareholder perspectives, these studies have implicitly placed the market at the centre of top managements' decision-making process for share buybacks. Market-driven theories explaining decisionmaking processes for share buybacks are powerful but are not convincing for those who highlight the limitations of market mechanisms and raise the strength of stakeholder power. Our study connects the stance of literature on pay-out policies and adds to the explanation of the incentives of stakeholders on corporate share buybacks. Particularly, it provides new insights into managerial decisions and their relative dominance vis-à-vis market-based incentives. These insights consider a mix of financial and managerial issues related to a firm's corporate management, ownership structure, capital structure, and strategic considerations.

Based on the examination of various stakeholders from eight listed UK firms over the 20112013 period, we find some evidence that, contrary to prior research, share buyback schemes are significantly more influenced by managerial long-termism than managerial short-termism. In addition, we found that managers consider non-investor stakeholders"' concerns as much as investor shareholders' in making share buyback decisions. This is surprising given that most prior research has stressed the importance of short-term financial market pressures on firms' decisions regarding share buybacks. Overall, our findings suggest that shareholders' perspectives do not differ from other stakeholders with regard to decisions to undertake share buybacks. Firms in our sample have articulated significant stakeholder considerations during this process. Our findings also suggest that short-term market pressures are not strong among firms undertaking long-term corporate decisions. Moreover, we find that corporate communication and effective systems of internal coordination of different functional groups within the organisations play an important role in share buyback decisions as they enable managers to align their different interests to avoid conflict among senior managers. Such findings are not related only to institutional shareholders but also to other non-investor stakeholders. To wit, we suggest that the constant challenges arising from the involvement of several stakeholders may not be resolved by simply aligning the myriad of stakeholders' plural incentives "trickling down" with corporate decisions that place markets at their centre. 
These findings have significant implications for the design of corporate pay-out policies and contribute to the debate on the motivations of share repurchases decisions, where there are conflicting short-term financial and strategic objectives among stakeholder groups. To develop successful share buyback programmes, companies will need to think of the limitations of market-driven policy considerations and deeply consider employing long-term strategic logic. Finally, although this study provides an insightful analysis of the factors affecting top management decisions on their share buyback processes, our findings are limited to the companies interviewed and cannot be generalised across all listed companies. 


\section{References}

Abyad, A. (2013), "Shareholders vs stakeholders the battle continues", Middle East Journal of Business Vol. 8, pp. 15-21.

Adhikari, B. K. and Agrawal A. (2018), "Peer influence on payout policies", Journal of Corporate Finance Vol. 48, pp. 615-637.

Ahmed, S., Bangassa, K. and Akbar S. (2020), "A study on trust restoration efforts in the UK retail banking industry", The British Accounting Review Vol. 52, pp. 1-18.

Almeida, H., Fos, V. and Kronlund. M. (2016), "The real effects of share repurchases", Journal of Financial Economics Vol. 119, pp. 168-185.

Andriosopoulos, D. and Hoque, H. (2013), "The determinants of share repurchases in Europe", International Review of Financial Analysis, Vol. 27, pp. 65-76.

Autore, D. M., Clarke, N. and Liu, B. (2019), "Activist investors and open market share repurchases", Journal of Banking and Finance, Vol. 107, pp. 1-17.

Accessed 23.05.2020.

Barton, D., Bailey, J. and Zoffer, J. (2016), "Rising to the challenge of short-termism", FTLC Global. Working paper. Retrieved from https://www.fcltglobal.org/resource/rising-to-thechallenge-of-short-termism/. Accessed 01.05.2020.

BEIS (2019), "Share repurchases, executive pay and investment", Working Paper 2019/11. Retrieved from https://assets.publishing.service.gov.uk/government/uploads/system/uploads/attachment d ata/file/817978/share-repurchases-executive-pay-investment.pdf. Accessed 01.05.2020.

Bivens, L. H. and Weller, C.E. (2005) "Corporate governance and the "job loss" recovery", Review of Radical Political Economics, Vol. 37, pp. 293-301.

Bloomberg (2020), "U.K. banks scrap dividends, buybacks after regulator push", Retrieved from https://www.bloomberg.com/news/articles/2020-03-31/u-k-banks-delay-dividend-atregulator-request-over-virus-tumult. Accessed 25.05.2020.

Braun, V. and Clarke, V. (2006), "Using thematic analysis in psychology", Qualitative Research in Psychology, Vol. 3, pp. 77-101.

Brav, A., Graham, J, Harvey, C. and Michaely, R. (2005), "Payout policy in the 21st Century", Journal of Financial Economics, Vol. 77, pp. 483-527.

Brockman, P., Khurana, I. K. and Martin, X. (2008), "Voluntary disclosures around share repurchases", Journal of Financial Economics, Vol. 89, pp. 175-191.

Buono, A.F. and Nichols, L. T. (1990), "Stockholder and stakeholder interpretations of business' social role", Business Ethics, Vol. 2, pp. 170-175.

Carlsson-Wall, M., Kraus, K. and Lind, J. (2015), "Strategic management accounting in close inter-organisational relationships", Accounting and Business Research, Vol. 45, pp. 27-54.

Chang, S., and Sullivan, M.J. (2007), "The disparate nature of targeted repurchases: Evidence from long-run performance", Journal of Business Finance \& Accounting, Vol. 34, pp. 6577.

Chen, S.S., Chen, Y.S. and Wang, Y. (2015), "Does labor power affect the likelihood of a share repurchase? Financial Management", Vol. 44, pp. 623-653.

Coleman, L., Maheswaran, K., and Pinder, S. (2010), "Narratives in managers' corporate finance decisions", Accounting and Finance, Vol. 20, pp. 605-633

Companies Act 1985, available on the internet at https://www.legislation.gov.uk/ukpga/1985/6/contents. Accessed 17.08.2018).

Companies Act 2006, available on the internet at

http://www.legislation.gov.uk/ukpga/2006/46/contents. (Accessed 17.08.2018).

Cornell, B., and Shapiro, A. C. (1987), "Corporate stakeholders and corporate finance", Financial Management, Vol. 16, pp. 5-14. 
De Jong, A., Martens, G., van der Poel, P. and van Dijk, R. (2013), "How does earnings management influence investor's perception of firm value? Survey evidence from financial analysts", Review of Accounting Studies, Vol. 19, pp. 606-627

Dedman, E., Kungwal, T. and Stark, A. W. (2014), "The information content of regular dividends and share repurchases for market value and future earnings in the UK", Working Paper. Retrieved from https://papers.ssrn.com/sol3/papers.cfm?abstract id=2518480. Accessed 15.01.2015.

Demirag I.S. (1995a), "Assessing short-term perceptions of group finance directors of UK companies", The British Accounting Review, Vol. 27, pp. 247-281.

Demirag I.S. (1995b), "Boards of Directors' short-term perceptions and evidence of managerial short termism in the UK", The European Journal of Finance, Vol. 4, pp. 195-211.

Demirag I., Tylecote A. and Morris, B. (1994), Accounting for financial and managerial causes of short-term pressures in British Corporations, Journal of Business Finance \& Accounting, Vol. 21, No 8, pp.1195-1213.

Dhanni A. and Roberts R. (2009), Corporate share repurchases: The perceptions and practices of UK financial manager and corporate investors. The Institute of Chartered Accountants of Scotland.

Dittmar, A.K. (2000), "Why do firms repurchase stock?", The Journal of Business Vol. 73, pp. 331-355.

Dittmar, A. and Field, L.C. (2015), "Can managers time the market? Evidence using repurchase price data", Journal of Financial Economics, Vol. 115, pp. 261-282.

Dixon, R., Palmer, G., Stradling, B. and Woodhead, A. (2008), "An empirical survey of the motivation for share repurchases in the UK", Managerial Finance, Vol. 34, pp. 886-906.

Edmans, A. (2020). Grow the Pie: How Great Companies Deliver both Purpose and Profit. Cambridge: Cambridge University Press.

Farrell, K.A., Yu, J. and Zhang, Y. (2013), "What are the characteristics of firms that engage in earnings per share management through share repurchases? ", Corporate Governance: An International Review, Vol. 21, pp. 334-350.

Financial Conduct Authority (2016), "Dealing in own securities and treasury shares:Premium listing", https://www.handbook.fca.org.uk/handbook/LR/12/4.pdf. Accessed 10.04.18.

Forbes (2020) "There's a strong case for Google to double down on Share Repurchases", Retrieved from https://www.forbes.com/sites/greatspeculations/2020/02/17/theres-astrong-case-for-google-to-double-down-on-share-repurchases/\#7f95f40fe489. Accessed 25.05.2020.

Freeman, R.E. (1984), "Strategic management, A stakeholder approach", Pittman Books Limited.

Fried, J. (2005), "Informed trading and false signalling with open market repurchases", California Law Review, Vol. 93, No 5, pp. 1323-1386.

Friedman, M. (1970), "The social responsibility of business is to increase its profits", N.Y. Times, Section 6, 126-127.

Gasper, J.M., Massa, M., Matos, P., Patgiri, R. and Rehman, Z. (2013), "Payout policy choices and shareholder investment horizons", Review of Finance, Vol. 17 No 1, pp. 261-320.

Geiler, P. and Renneboog, L. (2010), "Taxation of dividends and share repurchases in the UK", Tilburg University, Mimeo.

Geiler, P. and Renneboog, L. (2015), "Taxes, earnings payout, and payout channel choice", Journal of International Financial Markets, Institutions \& Money, Vol. 37, pp. 178-203.

Geiler, P. and Renneboog, L. (2016), "Executive remuneration and the payout decision", Corporate Governance: An International Review, Vol. 24, pp. 42-63. 
Ghaly, M., Dang, V.A. and Stathopoulos, K. (2020), "Institutional investors' horizons and corporate employment decisions", Journal of Corporate Finance, 101634.

Ginglinger, E. and L'Her, J.F. (2006), "Ownership structure and open market stock repurchases in France", The European Journal of Finance, Vol. 12, pp. 77-94.

Gomes, R.C. Liddle, J. and Gomes, L.O.M. (2010), "A five-sided model of stakeholder influence", Public Management Review, Vol. 12, pp. 701-724.

Grullon, G. and Ikenberry, D. (2000), "What do we know about share repurchases?", Journal of Applied Corporate Finance, Vol. 13 No 1, pp. 31-51.

Grullon, G. and Michaely, R. (2002), "Dividends, share repurchases and the substitution hypothesis", The Journal of Finance Vol. 57, pp 1649-1684.

Grullon, G. and Michaely, R. (2004), "The information content of share repurchase programs", The Journal of Finance, Vol. 59 No 2, pp. 651-680.

Gryglewicz S., Mayer S., and Morellec, M. (2020), "Agency conflicts and short- vs longtermism in corporate policies", Journal of Financial Economics Vol. 136, pp. 718-742.

Hillert, A. Maug, E. and Obernberger, S. (2016), "Stock repurchases and liquidity", Journal of Financial Economics, Vol. 119, pp. 186-209.

Hribar, P. Jenkins, N.T. and Johnson, W.B. (2006), "Stock repurchases as an earnings management device", Journal of Accounting and Economics, Vol. 41, pp. 3-27.

Ikenberry, D. and Vermaelen, T. (1996), "The option to repurchase stock", Financial Management, Vol. 25, pp. 9-24.

Jagannathan, M., C.P. Stephens, and M.S. Weisbach, 2000, Financial flexibility and the choice between dividends and stock repurchases", Journal of Financial Economics, Vol. 57, pp. 355-384.

Jagannathan, M. and Stephens, C. (2003), "Motives for multiple open-market repurchase programs", Financial Management 32, 71-91.

Jensen, M. (2002), "Value maximization, stakeholder theory, and the corporate objective function", Business Ethics Quarterly, Vol. 12, pp. 235-256.

Kahle, K.M. (2002), "When a buyback isn't a buyback: Open market repurchase and employee options", Journal of Financial Economics, Vol. 63, pp. 235-261.

Kajula J., Heikkinen, A. and Lehtimaki H. (2012), "Understanding the nature of stakeholder relationships:An empirical examination of a conflict situation", Journal of Business Ethics, Vol. 109, pp. 53-65.

Kaplan, S. (2018), "Are U.S. companies too short-term oriented? Some thoughts", Journal of Applied Finance, Vol. 30, pp. 8-18.

Karpoff J.M. (2021), "On a stakeholder model of corporate governance", Financial Management, Vol. 44, pp. 623-653.

Kim, J., Schremper, R. and Varaiya, N.P. (2013), "Open market repurchase regulations: A cross-country examination", Corporate Financial Review, Vol. 9, pp. 29-38.

Kinley, D. and Tadaki, J. (2004), "From talk to walk: The emergence of human rights responsibilities for corporations at international law", Virginia Journal International Law, Vol. 44, pp. 931-953.

Kulchania M. (2016), "Cost structure and payout policy", Financial Management, Vol. 44, pp. 623-653.

La Porta, R., Lopez-de-Silanes, F., Shleifer, A. and Vishny, R. (2000), "Agency problems and dividend policies around the world", Journal of Finance, Vol. 55, pp. 1-33.

Lazonick, W. (2014), "Profits without prosperity", Harvard Business Review.

Lease, C.R., John, K., Kalay, A., Loewenstein, U. and Sarig, O.H. (2000), "Dividend policy:Its impact on firm value", Harvard Business School Press. 
Llewellyn, S. (1999), "Narratives in accounting and management research", Accounting, Auditing \& Accountability Journal, Vol. 2, pp. 220-237.

Mitchell, J.D., Dharmawan, G.V. and Clarke, A.W. (2001), "Managements' views on share buy-backs: An Australian survey", Accounting and Finance, Vol. 41, pp. 93-2019.

Nguyen, L., Vu, L. and Yin, X. (2020), "Share repurchases and firm innovation", Accounting and Finance, Vol. 61, pp. 1-31.

Oswald, D. and Young, S. (2008), "Share reacquisitions, surplus cash, and agency problems", Journal of Banking \& Finance, Vol. 32, pp. 795-806.

Ota, K., Kawase, H. and Laub, D. (2019), "Does Reputation Matter? Evidence from Share Repurchases", Journal of Financial Economics 58, 287-306.

Peyer, U. and Vermaelen, T. (2009), "The nature and persistence of buyback anomalies", The Review of Financial Studies, Vol. 22, pp. 1693-1745.

Porter, M. (1992), "Capital Choices: Changing the Way America Invests in Industry", Boston, MA: Harvard University Business School Council on Competitiveness.

Rasbrant, J. (2011), "The price impact of open market share repurchases", Retrieved from http://ssrn.com/abstract $=1780967$. Accessed 31.07.2019.

Rau, R., and Vermaelen, T. (2002), "Regulation, taxes, and share repurchases in the U.K", Journal of Business, Vol. 75, pp. 245-282.

Renneboog, L., and Trojanowski, G. (2011), "Patterns in payout policy and payout panel choice", Journal of Banking \& Finance, Vol. 35, pp. 1477-1490.

Reynolds, S.J., Schultz, F.C. and Hekman, D.R. (2006), "Stakeholder theory and managerial decision-making constraints and implications of balance stakeholder interests", Journal of Business Ethics, Vol. 64, pp. 285-301.

Securities and Exchange Commission (2019), "The Boeing company: Shareholder proposal regarding shareholder authorizations of share buybacks", Retrieved from https://www.sec.gov/divisions/corpfin/cf-noaction/14a8/2020/mcritchieyoungboeing010920-14a8.pdf. Accessed 23.05.2020

Stonham, P. (2002), "A game plan for share repurchases", European Management Journal, Vol. 20, pp. 37-44.

Vermaelen, T. (2005), "Share Repurchases", Now Publishers, Hanover, MA.

Von Eije, H. and Megginson, W.L. (2008), "Dividends and share repurchases in the European Union", Journal of Financial Economics, Vol. 89, pp. 347-374. 
Figure 1. Overview of investors and non-investors in UK share buybacks operations.

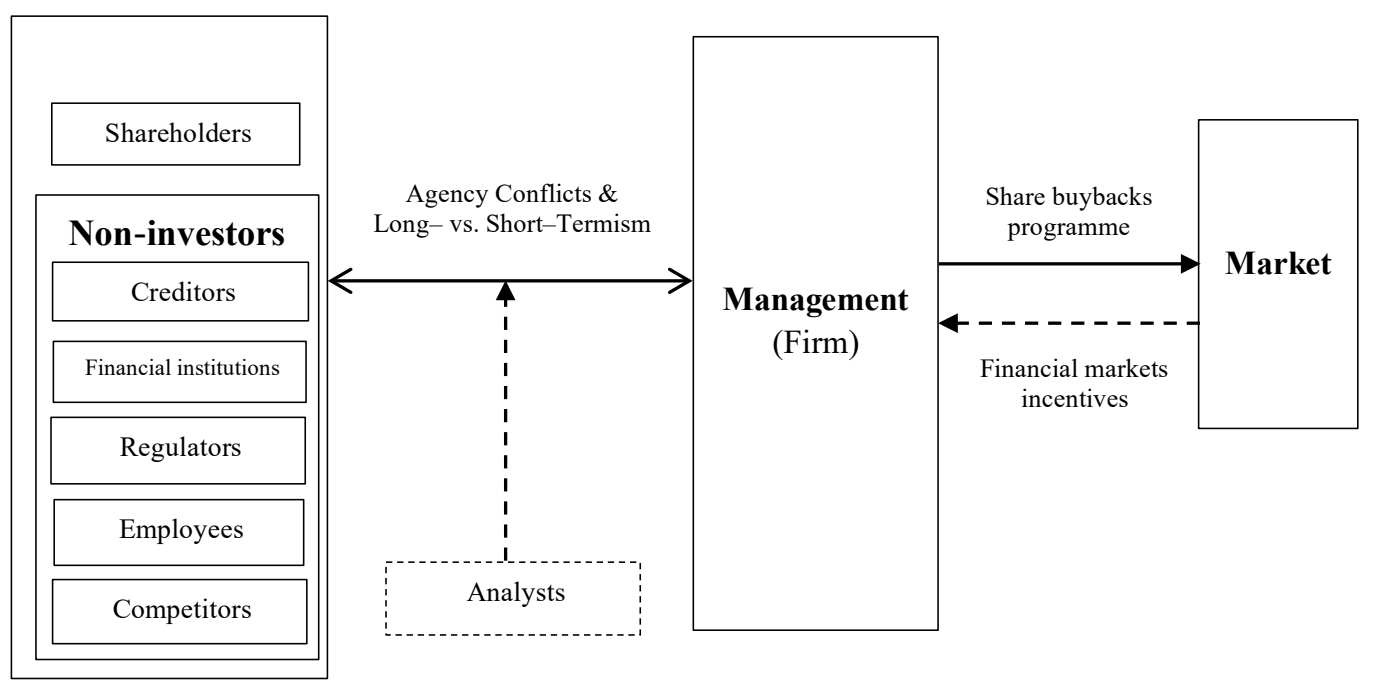


Table 1. Data source and interviews schedule table.

\begin{tabular}{|c|c|c|c|c|}
\hline $\begin{array}{l}\text { Organisation } \\
\text { (Industries) }\end{array}$ & $\begin{array}{l}\text { Interviewee } \\
\text { (Positions) }\end{array}$ & $\begin{array}{c}\text { Length } \\
\text { (Minut } \\
\text { es) } \\
\end{array}$ & Type & Date \\
\hline Industrials & $\mathrm{CFO}$ & 65 & Face to face & $\begin{array}{l}\text { Friday } 12^{\text {th }} \text { June } 2015 \text {, at } \\
3.00 \mathrm{pm}-4.05 \mathrm{pm} \text {. }\end{array}$ \\
\hline Industrials & $\begin{array}{l}\text { Investor Relations } \\
\text { Director }\end{array}$ & 93 & Face to face & $\begin{array}{l}\text { Thursday } 2^{\text {nd }} \text { June } 2016 \text {, } \\
\text { at } 4.00 \mathrm{pm}-5.33 \mathrm{pm} .\end{array}$ \\
\hline Telecommunications & $\begin{array}{l}\text { Investor Relations } \\
\text { Director }\end{array}$ & 63 & Face to face & $\begin{array}{l}\text { Thursday } 18^{\text {th }} \text { June } 2016 \text {, } \\
\text { at } 1.00 \mathrm{pm}-2.03 \mathrm{pm} .\end{array}$ \\
\hline Industrials & $\begin{array}{l}\text { Director of } \\
\text { Corporate } \\
\text { Finance }\end{array}$ & 48 & Face to face & $\begin{array}{l}\text { Thursday } 21^{\text {st }} \text { April 2016, } \\
\text { at } 12.00 \mathrm{pm}-12.48 \mathrm{pm} .\end{array}$ \\
\hline Utilities & Group Director & 37 & Face to face & $\begin{array}{l}\text { Wednesday } 27^{\text {th }} \text { April } \\
\text { 2016, at } 12.00 \text { pm-12.37 } \\
\text { pm. }\end{array}$ \\
\hline Telecommunications & Group Director & 65 & Face to face & $\begin{array}{l}\text { Tuesday } 31^{\text {st }} \text { May } 2016 \text {, } \\
\text { at } 1.00 \mathrm{pm}-2.05 \mathrm{pm} .\end{array}$ \\
\hline Industrials & Group Treasurer & 81 & Face to face & $\begin{array}{l}\text { Thursday } 2^{\text {nd }} \text { June } 2016 \text {, } \\
\text { at 2:00 pm-3.21 pm. }\end{array}$ \\
\hline Financial services & $\begin{array}{l}\text { Managing } \\
\text { Director }\end{array}$ & 40 & Face to face & $\begin{array}{l}\text { Wednesday } 22^{\text {nd }} \text { June } \\
\text { 2016, at } 10.00 \text { am- } 10.40 \\
\text { am. }\end{array}$ \\
\hline Oil \& gas & Group Treasurer & 88 & Face to face & $\begin{array}{l}\text { Friday 17th June 2016, at } \\
9.00 \mathrm{am}-10.28 \mathrm{am} .\end{array}$ \\
\hline
\end{tabular}


Table 2. Phases of the thematic analysis.

\begin{tabular}{ll}
\hline \multicolumn{1}{c}{ Phase } & \multicolumn{1}{c}{ Description of the process } \\
\hline $\begin{array}{l}\text { 1. Reviewing data } \\
\text { 2. Creating relevant idea codes } \\
\text { 3. Preparing for themes }\end{array}$ & $\begin{array}{l}\text { Reading through all transcriptions and identifying relevant ideas. } \\
\text { Creating relevant ideas to each code. } \\
\text { Organising codes into potential themes, collecting all data related to } \\
\text { each potential theme. } \\
\text { Checking across the thematic map to see whether all themes are } \\
\text { coordinated and they supported by relevant codes and data. }\end{array}$ \\
4. Reviewing themes & $\begin{array}{l}\text { Refining the specifics of each theme and naming themes. } \\
\text { Analysing, and compelling extract examples relating back to the } \\
\text { analysis of the research question and the literature, producing an } \\
\text { analysis report. }\end{array}$ \\
\hline
\end{tabular}


Table 3. Main themes and sub-themes developed from thematic analysis approach.

\begin{tabular}{|c|c|c|}
\hline Main themes & Sub-themes & Other variables \\
\hline \multirow[t]{5}{*}{ Financial factors } & Financial structure & $\begin{array}{l}\text { - External sources of financing (equity issues, debt } \\
\text { financing, repurchases, and leveraging). } \\
\text { - Internal sources of financing (higher or lower } \\
\text { earnings retention, and size adjustment). }\end{array}$ \\
\hline & Excess cash flows & $\begin{array}{l}\text { - Sources of cash flow (operating, investing, and } \\
\text { financing cash flows). } \\
\text { - Persistency (temporary and permanent excess cash } \\
\text { flow). }\end{array}$ \\
\hline & $\begin{array}{l}\text { Financial strategy } \\
\text { and performance }\end{array}$ & $\begin{array}{l}\text { - Short-term strategy (dividends payment, and shares } \\
\text { buyback). } \\
\text { - Long-term strategy (M\&A activity, growth strategy, } \\
\text { internationalisation, and R\&D investment). }\end{array}$ \\
\hline & Share price signalling & $\begin{array}{l}\text { - Information asymmetry. } \\
\text { - Undervalued/overvalued share prices. } \\
\text { - Improvement of share prices and EPS. }\end{array}$ \\
\hline & Agency problem & $\begin{array}{l}\text { - Transparency. } \\
\text { - Accountability (CSR strategy, ESG disclosures, and } \\
\text { ethics). } \\
\text { - Remuneration to management (ESOP, and SDP). } \\
\text { - Return to shareholders (dividend payment and share } \\
\text { buyback). }\end{array}$ \\
\hline \multirow[t]{5}{*}{$\begin{array}{l}\text { Non-financial } \\
\text { factors }\end{array}$} & $\begin{array}{l}\text { Regulatory } \\
\text { requirements }\end{array}$ & $\begin{array}{l}\text { - Compliance with regulations (Company Act } 2006 \text {, } \\
\text { accounting standards, UK tax pay-out code } 1997 \text {, } \\
\text { and stock exchange regulations regarding different } \\
\text { offers to share buybacks). } \\
\text { - Credit ratings. }\end{array}$ \\
\hline & Relationships & $\begin{array}{l}\text { - Communication channels to stakeholders (internal } \\
\text { channels, and external channels). } \\
\text { - Coordination (internal and external coordination } \\
\text { between units) } \\
\text { - Trust and loyalty. } \\
\text { - Responsibility. }\end{array}$ \\
\hline & Market and industry & $\begin{array}{l}\text { - Market cycle (introduction, growth, mature, and } \\
\text { decline stages) } \\
\text { - Types/natures of industry. }\end{array}$ \\
\hline & Competition & - Level of competition. \\
\hline & $\begin{array}{l}\text { Organisational } \\
\text { structure }\end{array}$ & $\begin{array}{l}\text { - Hierarchy (centralised or decentralised organisational } \\
\text { structure). } \\
\text { - Ownership structure and changes. } \\
\text { - Control chain (control rights, cash flow rights, excess } \\
\text { control rights, and pyramidal structures). }\end{array}$ \\
\hline
\end{tabular}




\section{$\underline{\text { Appendix A }}$}

Questions to companies:

- Who initiated the share buyback programme in your organisation during the last financial year?

- Was this a result of a regular financial management control decision or based on ad hoc analysis? Please explain.

- Are there any financial control systems in your company to monitor share buybacks every year? Please explain.

- Who makes the final decision? Is this a senior financial management decision or a decision taken by the board of directors? Please explain.

- Are institutional shareholders informed/consulted before the share buyback announcement? If so how; please explain.

- Are pension funds or other institutional investor managers been consulted? If so, have there been any disagreements in the last financial share buyback programme. Please give examples.

- Have share buyback decisions been discussed with senior functional managers such as production, finance, marketing, etc? Please explain.

- Are Trade Unions consulted on share buyback programmes?

- To what extent share buyback decision is based on pressures from financial analysts?

Please identify any other issues which we should explore further in our research. 